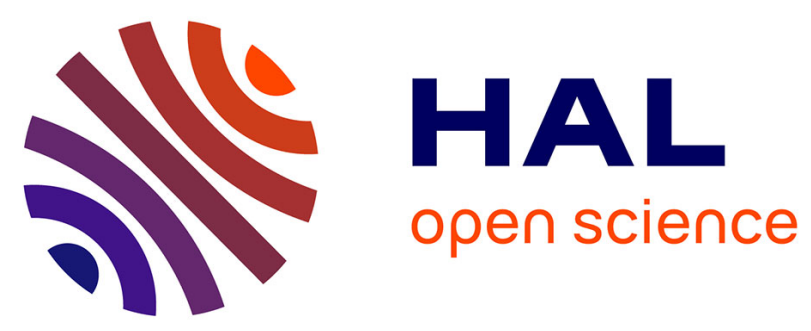

\title{
Functional and positional genomics in beef cattle: current programs and potential progress
}

Jean-François J.-F. Hocquette, Didier Boichard, Isabelle Cassar-Malek, Elisabeth Laville, Gilles G. Renand, Hubert H. Levéziel, Brigitte B. Picard

\section{- To cite this version:}

Jean-François J.-F. Hocquette, Didier Boichard, Isabelle Cassar-Malek, Elisabeth Laville, Gilles G. Renand, et al.. Functional and positional genomics in beef cattle: current programs and potential progress. Sciences des aliments $=$ Food science : an international journal of food science and technology, 2008, 28 (4-5), pp.335-350. 10.3166/sda.28.335-350 . hal-02663499

\section{HAL Id: hal-02663499 \\ https://hal.inrae.fr/hal-02663499}

Submitted on 31 May 2020

HAL is a multi-disciplinary open access archive for the deposit and dissemination of scientific research documents, whether they are published or not. The documents may come from teaching and research institutions in France or abroad, or from public or private research centers.
L'archive ouverte pluridisciplinaire $\mathbf{H A L}$, est destinée au dépôt et à la diffusion de documents scientifiques de niveau recherche, publiés ou non, émanant des établissements d'enseignement et de recherche français ou étrangers, des laboratoires publics ou privés. 


\title{
Functional and positional genomics in beef cattle: current programs and potential progress
}

\author{
J.-F. Hocquette ${ }^{1 *}$, D. Boichard², I. Cassar-Malek ${ }^{1}$ E. Laville ${ }^{3}$, G. Renand², \\ H. Levéziel ${ }^{4,5}$, B. Picard ${ }^{1}$
}

\begin{abstract}
RÉSUMMÉ
Des avancées en génomique fonctionnelle et positionnelle chez les bovins: programmes en cours et potentialités

La génomique est une véritable révolution de la biologie aux nombreuses applications potentielles dans toutes les sciences de la vie. Par l'analyse simultanée d'un grand nombre de gènes, de protéines et de métabolites, la génomique ouvre de nouvelles perspectives pour de nombreux programmes de recherche dont l'objectif est de mieux maitriser la qualité de la viande bovine (en particulier sa tendreté) par les facteurs génétiques ou physiologiques. En effet, la tendreté est un caractère complexe qui dépend de l'interaction entre un grand nombre de gènes associés à la matrice conjonctive, aux propriétés contractiles et métaboliques des fibres musculaires et aussi à la protéolyse post-mortem. Le séquençage complet du génome bovin et la disponibilité de puces de génotypage à haut débit favorisent la mise en évidence de marqueurs génétiques de la qualité de la viande et le développement de la sélection assistée par marqueurs et aussi de la sélection génomique. De la même façon, la transcriptomique et la protéomique ont facilité l'étude du développement du muscle et de l'hypertrophie musculaire de même que la mise en évidence de nouveaux marqueurs biologiques de la qualité de la viande bovine. Le développement de la métabolomique est également en cours. En raison des progrès dans les techniques de génomique, le nouveau front de science est maintenant le développement du phénotypage à haut débit de même que celui des approches de modélisation pour mieux prédire la qualité de la viande bovine à partir des marqueurs génomiques déjà identifiés.
\end{abstract}

\section{Mots clés}

qualité de la viande bovine, tendreté, marqueurs génétiques, transcriptomique, protéomique.

1. INRA - UR1213 - Unité de recherches sur les Herbivores - Theix - 63122 Saint-Genès-Champanelle France.

2. INRA - UMR1313 - Génétique Animale et Biologie Intégrative - 78350 Jouy-en-Josas - France.

3. INRA - UR370 - Unité Qualité des Produitș Animaux - Theix - 63122 Saint-Genès-Champanelle France.

4. INRA - UMR1061 - Unité de Génétique Moléculaire Animale - 87000 Limoges - France.

5. Université de Limoges - UMR1061 - Unité de Génétique Moléculaire Animale - 87000 Limoges - France.

* Correspondence: jfhocquette@clermont.inra.fr 


\section{SUMMIARY}

Genomics has brought with it a true biological revolution and has a great number of potential applications in all areas of life sciences. Thanks to the simultaneous analysis of vast numbers of genes, proteins and metabolites, genomics opens up new perspectives for a host of research programs in the genetic and physiological control of beef quality especially tenderness. Indeed, tenderness is a complex trait which depends on interplay between a great number of interacting genes associated with connective tissue, the contractile and metabolic characteristics of muscle fibres as well as proteolysis during aging. The completed bovine genome sequence and the availability of high-throughput genotyping chips help the discovery of genetic markers for beef quality and the development of marker-assisted selection and of "genomic selection". Meanwhile, transcriptomics and proteomics have favoured the study of muscle development and of muscle hypertrophy as well as the discovery of new biological markers of beef quality. The development of metabolomics is in progress. Thanks to the development of genomics, the new challenge is now to develop high-throughput phenotyping as well as modelling approaches to better predict beef quality from the different genomic markers so far identified.

\section{Keywords}

beef quality, tenderness, genetic markers, transcriptomics, proteomics.

\section{1 - INTRODUCTION}

Although methodological developments still need to be made, genomics approaches have revolutionized scientific inquiry by offering unparalleled investigative capacities that make it possible to study the entire genome of an individual organism or to simultaneously analyze all its gene expression products. The scope of potential for genomics applications in the life sciences, and especially in medicine, is driving a number of challenges and choices. These challenges extend to cattle farming, where they are equally important in animal genetics as in animal physiology. With the vast numbers of genes, proteins and metabolites that can be analyzed together, genomics opens up new perspectives for a host of research programs focused on animal metabolism, health and welfare, as well as on product quality. This review article is intended as a progress report covering the advances made to date in beef production and highlighting the key future perspectives. Broadly speaking, physiological processes are generally dependent on interplay between the expression of a number of interacting genes. This is particularly true for beef quality and particularly tenderness, which is the result of complex multifactorial processes. Baseline tenderness is actually linked to the characteristics of the connective tissue, whereas the tenderness of the myofibrillar fraction is dependent on the contractile and metabolic characteristics of muscle fiber as well as on proteolytic effects occurring during ageing. Numerous animal-related factors (age, breed, genotype, and gender), farming system-related factors (growth rate, diet) or even postmortem technological factors all induce changes in muscle characteristics that translate into variations in meat quality and tenderness. However, less than a third of the variation in organoleptic quality is due to variation in the muscle characteristics of the live animal (Renand et al., 2001). Using genomics techniques to identify new 
biological markers and learn how they are regulated by farming-related factors has therefore become a primary focus of research in controlling meat quality. The target for animal genetics is to generate a set of markers that will improve the process of selecting animals with the potential to consistently produce high-quality meat.

\section{2 - A BETTER UNDERSTANDING OF GENOMES}

\subsection{Recent advances in knowledge of the bovine genome}

The haploid bovine genome includes over 3 billion nucleotide base pairs spread over 30 pairs of chromosomes. This very large size has long prevented the scientific community to obtain, and even to hope to obtain, the complete sequence. Indeed, the sequencing programs were for a long time focused on small genomes and the huge cost of the human genome sequencing made it impossible to carry out similar work on cattle. From the early 1990s until the early 2000s, the strategy used to characterize the genome was based on three ideas:

1) the construction of maps with higher and higher resolutions, allowing the location of genes and markers on the genome;

2) the construction of comparative maps, taking advantage of the conservation of genomes between species and, thus, allowing researchers to infer the structure of the bovine genome from information on other genomes, particularly those better known in the mouse and human;

3) the sequencing focused on regions of interest, especially expressed genes.

During this period, the following were developed: thousands of genetic markers, mainly microsatellites, used to construct genetic maps; radiation hybrid $(\mathrm{RH})$ maps, based on an efficient and inexpensive technology allowing the mapping of sequences to each other with a high resolution; the construction of libraries of DNA fragments of varying size, up to $200 \mathrm{~kb}$, which enable to study a large region as such, especially by sequencing; then physical maps, made of several tens of thousands of $100-200 \mathrm{~kb}$ long overlapping fragments, so covering the entire genome (Schibler et al., 2004; Snelling et al., 2007). From a comparative point of view, chromosome painting analysis carried out in the middle of the nineteen-nineties already gave a good but macroscopic view of synteny conservation between species. The resolution was considerably improved by $\mathrm{RH}$ maps that provide the position of several thousands of genes in different species (e.g. Gautier et al., 2003). In the early 2000s, these tools were available and allowed to search for genes responsible for the variability of traits, using a classical genetic approach as follows:

1) search for an association between genetic markers and phenotype in an appropriate experimental design;

2) development of new markers within the region and fine mapping;

3) search for candidate genes in the region, taking advantage of comparative analysis between species.

The emergence of large sequencing resources, the mobilization of considerable fundings, and especially the drastic decrease in the sequencing cost have led to the launching of complete genome sequencing programmes for a growing number of species. Through its strong and deeply involved international scientific community 
and because of fully available physical and $\mathrm{RH}$ maps, the bovine genome has been one of the first major domestic animal genomes to be sequenced, after the chicken and the dog. Funding has been largely of American origin $(\mathrm{NIH}$, State of Texas, USDA). The first sequence draft was released in the summer of 2006 by the Baylor College of Medicine in Houston. Thereafter, the depth of sequencing (i.e. the ratio between the number of bases sequenced and the number of bases of the genome) was increased to exceed $7 X$ (which means that a given sequence is present on average 7 times in the database). Moreover, the quality of assembly has gradually improved so that the quality of the following versions of the bovine genome sequence was increasing. To date, the sequence quality is fairly good, although there are still many holes. The arrival of this extraordinary tool modifies to a large extent the working methods, provides direct access to information which were laboriously generated before, and thus saves a lot of time and effort. It also allows carrying out very detailed bioinformatic analysis of the genome structure, alone or in comparison with other species, and often enables to discover hitherto unknown phenomena.

Sequencing the entire genome of a species is usually based on deep sequencing of a reference individual (in this case a Hereford female) but also on the partial sequencing of other individuals. Comparing these different sequences with that of the reference individual reveals a large number of polymorphisms. This approach has been used in cattle: the dbSNP database contains information on about 2.2 million detected SNP. In addition, tens of thousands of these SNP were validated by genotyping a reference panel, in order to verify their existence and to estimate allelic frequencies in different populations. More recently, a consortium has developed and validated new SNP markers taking advantage of the huge potential and low cost of the Solexa sequencing method (Van Tassell et al., 2008).

At the same time, several genotyping technologies have been developed. Those currently available, developed by Illumina and Affymetrix, are conceptually quite similar to the DNA chips proposed for gene expression studies. These chips can genotype tens of thousands (in humans hundreds of thousands) of polymorphisms simultaneously. The first chip available in cattle in 2004, developed by Affymetrix, allowed the genotyping of 10,000 SNP. Illumina's chip available in 2008 genotypes 54,000 SNP at a lower cost. This chip is currently the standard tool on the market and is used by the majority of cattle geneticists around the world. It opens up considerable opportunities in genetics, such as fine mapping of genes of interest, marker-assisted selection (MAS) or genomic selection, or analysis of genetic diversity.

\subsection{The search for genetic markers}

From the emergence of the first genetic maps (early 1990s) to the use of molecular information in breeding programs (early 2000), advanced knowledge of the bovine genome has been effectively used for dairy cattle improvement. These steps could not be undertaken as easily for meat production because appropriate resource populations were not so readily available, due to limited use of artificial insemination, and also because performance recording was less developed, and virtually absent for meat quality. Accordingly, any research project that aims at identifying genes and polymorphisms of interest relies on the establishment of a specific experimental design.

In Europe, several teams including those of INRA proposed in 1999 a European project that consisted of an exploratory approach based on candidate genes with the aim to identify genes and polymorphisms controlling part of the variability in 
meat quality characteristics. The GeMQual (Genetics of Meat Quality) programme was established in 2001. First, groups of 30 unrelated bulls representative of each of the 15 breeds studied were fattened to collect phenotypic measures in relation to carcass and meat qualities. Then, the identification of SNP within or near genes chosen on the basis of their physiological function was undertaken. The search for associations between polymorphisms and phenotype concerned 372 SNP (in 155 genes), 972 animals (434 bulls +538 parents) and 107 traits. Various statistical methods have led to the identification of 149 significant associations involving 33 genes (located on 17 chromosomes) and 87 different SNP. The number of associations by gene varies from 1 to 19 , a dozen genes giving rise to the majority (110) of them; the number of associations by SNP ranging from 1 to 12 . The majority of associations relates to the fatty acid composition of meat (64), the sensory qualities (32) or tenderness (21). Some associations are related to growth (13) or the color of meat (8). The analysis of such huge information, including data analysis taking into account haplotypes, is not yet completed. However, after this program, which has involved about thirty scientists, several general observations can be made:

1) The results show that there is a significant variability of phenotypes measured, between breeds and especially between animals within breeds. Especially for traits not subject to selection (adiposity, fat composition, and tenderness), the classification of animals and breeds varies according to the criteria. One can expect that improvements are possible, either by crossing between breeds or by selection within breed.

2) The search for genetic markers useful in selection is a long process: the initial results achieved by the GeMQual program are fewer than expected and this is explained not only by the size of the population studied but because it is not clear if allelic combinations are the same in all breeds. Having pointed out some genes of interest, the identification of causative mutations still requires further investigations. The most relevant situations to explore will have to be validated anyway, like any other situation revealed by research programs that are first "screening" the genome.

A number of research programs has been carried out for studying the genetic determinism and detecting genetic markers of beef meat quality (review of Renand et al., 2003). Most of the studies were implemented in the USA and Australia in the early 1990's followed by Canada and New Zealand and, more recently, Germany and Scotland. A number of results was published and some even patented. Genetic tests are presently available in these countries. They rely on markers expectedly related to marbling or tenderness of beef meat (review of Hocquette et al., 2007b).

In these studies, detection was generally conducted with crossbred animals. The results either published or not, cannot be directly extrapolated to the breeds exploited in these countries. Validation programs were currently implemented in Australia (Cooperative Research Centre for the Cattle and Beef Industry) and in the USA (Carcass Merit Project). More than 7,000 animals were included in these programs. Up to now, a limited number of markers have been tested. However detection and validation conditions differed markedly from the French beef production systems (breeds, age, sex, feeding systems) and the cooking habits of beef meat by the French consumer. The results therefore need to be validated in order to know if they can also be used for selection in France with some accuracy.

In France, a detection and validation program, named QUALVIGENE, was implemented in 2003 with the financial support of the Ministry of Agriculture, APIS-GENE, FNE and the "Office de l'Elevage". This program was designed to test in the main French beef breeds any DNA marker aiming at meat quality improvement. The QUALVIGENE program is based on 3,349 blond d'Aquitaine, charolais or limousin 
young bulls, progeny of 114 sires, fattened and slaughtered under controlled conditions. Twenty-four professional partners, including from the "Institut de l'Elevage" and INRA are involved in this program. A total of 98 phenotypes on beef traits, muscle characteristics and meat quality have been collected; all information was gathered in a consolidated database in late 2007. The analysis of the data enabled the first estimation of genetic parameters of beef meat quality in France highlighting the existence of a significant genetic variability in our breeds (Renand et al., 2006b, 2007). The available DNA of bulls and their parents (6,150 individuals in total) were genotyped at first for 48 markers (27 SNP and 21 microsatellites) corresponding to 12 genes and 1 chromosome region spread over 9 chromosomes. The CAPN1, CAST and LOX genes expectedly related to tenderness were elected as well as the DGAT1, FABP4, LEP, RORC and TG genes and a region of chromosome 5 (BTA5) expectedly related to marbling and the GDF8, IGF1, Myf5 and POMC for muscle growth. The existence of a consistent polymorphism was confirmed for these markers in the 3 breeds. A coefficient of heterozygosity over $80 \%$ among the sires can be achieved with 4 SNP for instance. It should be noted that at least one marker in the CAST gene, cited in an Australian patent, shows no polymorphism, which confirms the obligation to validate in our breeds. The data are currently being analyzed. Preliminary results confirm the positive effects of the Q204X mutation in the GDF8 gene for carcass and muscle characteristics of Charolais cattle (Renand et al., 2006a). The involvement of the DGAT1 and TG genes in intramuscular fat content was not confirmed (Renand et al., 2007), while these genes have been patented by foreign research laboratories.

The QUALVIGENE program also allowed, for the first time in France, undertaking QTL detection for carcass and meat qualities through the genotyping of 147 microsatellite markers, as a screening of the complete genome (genome scan) in the 6 largest families. The results are presently being analyzed. The use of the new genotyping tools now available and allowing the parallel analysis of 54,000 SNP would greatly improve our power of detection and the precision of QTL fine mapping. Currently, the best strategy for maximizing the effectiveness and cost of investigations is under theoretical definition.

If genetic markers are appropriate tools for selection, their detection remains difficult and it will probably not always be possible to fully "dissect" the genetic determinism of the character considered. So the power of genomics methodologies offers hope to detect "physiological" markers that could be used in combination with and complementary to genetic markers. Based on the collection of phenotypes more finely described, these "physiological" markers could serve as tools for predicting performance (such as meat tenderness). They can rely, for example, on measuring the expression of genes at the level of transcripts or proteins. Therefore, many functional genomics studies are presently concentrated on muscle and its biological characteristics.

\section{3- A BETTER UNDERSTANDING OF MUSCULAR BIOLOGY}

\subsection{Functional genomics approaches}

The strategy consists in the identification of the genes or proteins that are expressed differentially between extreme animals without any prior knowledge of the processes involved (review by Cassar-Malek et al., 2008). The various transcriptomic 
studies carried out in cattle have followed the technological progress made with DNA chips. So cDNA collections have been prepared from the genes expressed in the liver, intestine, embryo, endometrium, uterus, ovaries, or several bovine tissues together with the aim of preparing chips that can be used whatever the tissue examined. Korean, Australian and French researchers have contributed to this international effort by preparing cDNA collections from muscles alone or mixed with fatty tissues in order to achieve a maximum probability of studying the genes involved in muscle development and the accumulation of fat in meat (review by Hocquette et al., 2007b). Today, researchers are increasingly using microarrays which offer improved technical performance. Thus Bernard et al., (2007) in their study of bovine muscle, used oligonucleotide chips of human and murine muscle genes while INRA (CRB Gadie) produces and distributes a chip with 22,000 bovine oligonucleotides. A number of multinational companies (e.g.: Affymetrix, Agilent) offer pan-genomic chips for domestic species of interest, including cattle.

Proteins are the final product of gene expression. Although DNA chips potentially allow the expression of almost all genes to be analyzed, proteomic techniques provide the means for studying only the most abundant proteins under specific experimental conditions. To overcome these problems, it is sometimes necessary to work with subcellular fractions obtained by differential extraction protocols (Laville et al., 2007) and/or to repeat experiments under different $\mathrm{pH}$ conditions in order to detect more proteins (Chaze et al., 2008). However, it is extremely important to study the proteome because the protein may be absent even when the gene is present. Moreover, a protein may exist as various "isoforms" which are generally undistinguishable for the DNA chips. These "isoforms" are the product of post-translational modifications or may result from alternative splicing of mRNA. A good example of this is the $T$ troponin isoforms that are encoded by 3 different genes corresponding to the cardiac, slow and fast types, and for which 17 isoforms ( 6 slow and 11 fast) were found in bovine muscle (Bouley et al., 2005).

\subsection{Muscle development studies}

Myogenesis takes place during several temporally distinct phases: proliferation of precursor cells (myoblasts) in the first 180 days of foetal life, fusion of myoblasts into differentiated multinuclear cells (myotubes), and differentiation of these cells into muscle fibres during the final third of gestation. Analysis of the transcriptome (Sudre et al., 2003) and proteome (Chaze et al., 2008) in bovines has provided the means for describing certain gene expression profiles and proteins regulated during the development of muscle tissue. Thus Sudre et al., (2003) confirmed the physiological importance of the 180-day p.c. stage as an ontogenic transition point and the regulation of expression of a large number of genes during the differentiation period. This study also allowed various genes to be identified (Leu5, Trip 15, Siat8...), which are regulated during myogenesis but whose role in this development process remains to be clarified. In addition analysis of the semitendinosus (ST) muscle proteome revealed 248 proteins expressed differentially during myogenesis. Hierarchical classification analysis of the first three stages in gestation revealed several expression clusters mostly related with proliferation and cell death (Chaze et al., 2008). These results suggest that the balance between cell proliferation and apoptosis is crucial for controlling the total number of muscle fibres. In addition, potential new specific markers for regulation of the total number of fibres (WARS and DJ1 proteins) or proliferation of various generations of myoblasts (CLIC4 for primary myoblasts, HnRNPK for secondary myoblasts) have been identified. The final third of foetal life is above all marked by a considerable number of changes in the isoforms 
for contractile and metabolic proteins (myosin light chains, slow or fast $\mathrm{T}$ troponins or also alpha and beta enolases) (Chaze et al., 2008). So, a very rich map of ST muscle proteins during foetal life has been drawn up (Chaze et al., 2006) to accompany the map produced for adult muscle (Bouley et al., 2004a). These data concerning modifications in bovine muscle proteome during foetal life represent a reference for myogenesis studies in other types of bovines, and also for other species for comparative biology studies.

\subsection{Gene and protein expression profile according to the potential for muscle growth}

Muscle hypertrophy is of considerable economic importance because it is a way of increasing meat production. In cattle, increased muscle development is sometimes positively related with meat tenderness, but not with flavour. In agreement with the above cellular studies, transcriptomic analyses of rectus abdominis (oxidative) and semitendinosus (glycolytic) muscles of young bulls selected for their varying potential for muscle growth showed that selection on the basis of the growth rate results in reduced muscle oxidative activity. Similarly, certain genes involved in muscle structure or cell regulation are expressed more in young bulls with a low growth potential (Sudre et al., 2005). More recently, over-expression of 2/3 of glycolysis genes has been demonstrated in the longissimus thoracis muscle of young bulls with a high growth potential. Moreover the level of expression of genes (FGF6, $P L D 2$ ), that are known to be involved in muscle hypertrophy in rodents, has been correlated with the increase in muscle mass of young bulls independently of fat quantity. Finally it appears that the majority of genes whose expression is modified by genetic selection are different from those associated with meat sensorial qualities, suggesting that this selection may be of little consequence for the quality of meat produced by the animals studied (Bernard et al., 2009). On the contrary, certain proteins such as the T Troponin isoforms appear to be good markers for muscle hypertrophy and meat tenderness, indicating that there is no contradiction between an increase in muscle mass and improvement of sensorial quality (Bouley et al., 2004b and 2005).

Studies have also been led on the "double-muscled" breeds that present higher muscle mass and lower carcass and muscle fat content caused by mutations in the myostatin gene. Myostatin is a growth factor that inhibits muscle tissue growth. This means that any mechanism that cuts or deletes its action will induce strong muscle growth. The first description of the mutation, in the Belgian Blue breed (Grobet et al., 1997) spawned several other reports of mutations in other breeds. The common denominator is that the mutation deactivates the gene and the animals are doublemuscled (Grobet et al., 1998). Studies comparing the muscle transcriptome in double-muscled and non-double-muscled animals have underlined the important role of genes involved in connective tissue growth, muscle energy metabolism and muscle lipid metabolism (Cassar-Malek et al., 2007), as well as in apoptotic processes (Chelh et al., 2008).

In Texel sheep, which are also "hypermuscled", certain types of muscle like the vastus medialis do not exhibit hypertrophy. Proteomics analysis on four types of muscle has shown that the increase in muscle mass is associated with an up-regulated expression of energy metabolism enzymes, proteins regulating oxidative stress, and hypoxia marker transferrin. Alpha-1-antitrypsin is the only protein that is differential between the two haplotypes (double-muscled and non-doubled-muscled) regardless of muscle type (Hamelin et al., 2006). The gene responsible for the "hypermuscled" trait in Texel sheep, once again, is myostatin. The INRA, in partner- 
ship with the University of Liege, has identified the mutation that causes this trait. This mutation interferes with the production of myostatin by creating an illegitimate target site for microRNA on the RNA transcripts that leads to their degradation. Therefore, although the myostatin gene is expressed, the RNA are damaged, meaning that the myostatin protein cannot be synthesized normally, thereby resulting in the observed muscular hypertrophy (Clop et al., 2006). This research has thus revealed a type of genetic regulation with major phenotypic consequences. This mechanism is in fact an illustration of a general cellular process known as "RNA interference". RNA interference is one of the cell's natural defence mechanisms against viruses: the in-cell degradation of the virus's RNA (or RNA) prevents the infectious agent from spreading. In the USA, the in vivo manipulation of this cellular process is flourishing as a quick and easy strategy for identifying new pharmacological targets in the genes responsible for certain diseases. Certain authors predict that using this mechanism to experimentally deactivate genes in vitro will make it possible to study the biological function of the genes identified through techniques employed in functional genomics in cattle (Sellner et al., 2007).

\subsection{New markers revealed for meat quality}

It is widely accepted that the main factor for variations in beef tenderness is the type of muscle rather than the breed or type of animal. Transcriptomic studies on the differences between two types of beef muscle have revealed certain genes of interest with respect to the biology of the muscle, some of which are related to muscle contractile or metabolic properties. The differences between the types of muscle appear to depend on the stage of development (Sudre et al., 2003) and the animal's genetic type (Sudre et al., 2005).

Some of the people working in the beef industry are looking for genes capable of identifying animals with a high potential for accumulating intramuscular fat in order to produce marbled meat. This has resulted in Japanese and Australian findings concerning "Japanese Black" and "Holstein" breeds revealing genes associated with meat marbling (Wang et al., 2005), one of which (A-FABP) was also identified in France (Jurie et al., 2007). These results can also help with the implementation of production strategies aimed at controlling intramuscular fat development at the various stages in animal growth.

The goal of the MUGENE program (financed by the ANR and APIS-GENE) is to identify new markers for beef sensorial qualities using genomics approaches (Hocquette et al., 2007a). The expression level of a large number of genes and proteins was analysed in the longissimus thoracis muscle together with the biochemical characteristics of this muscle in young charolais bulls. The muscle transcriptomes and proteomes were compared on the basis of sensorial quality and shear force for the meat when grilled $\left(55^{\circ} \mathrm{C}\right)$. Among the markers identified, certain indicators of fatty acid oxidative metabolism in the muscles appear to be associated with meat of better flavour (cytochrome-c oxidase, PRKAG1 [AMP-activated protein kinase gamma 1 subunit]) or greater tenderness (citrate synthase, apoBEC, apolipoprotein, slow isoform of the myosin heavy chain, and ATP synthase beta chain). One important result is the identification of a negative relation between the expression of the DNAJA1 gene and meat sensorial tenderness after 14 days of ageing, not only in the young bulls in the study but also in Charolais steers (Bernard et al., 2007). This gene encodes a chaperone protein of the "heat shock" protein family (HSP40). The expression level of other stress proteins (notably HSPB1 encoding Hsp27) is positively correlated with the shear force, whether at the mRNA or protein level. These proteins have an anti-apoptotic activity and thus may slow down the cellular death 
process and consequently meat ageing, which would compromise the muscle tenderising process after slaughter.

In agreement with these results, Morzel et al., (2008) showed on semitendinosus muscle of young blond d'Aquitaine bulls that abundance of succinate dehydrogenase (SDH, an oxidative metabolism enzyme) appears to be the best predictor of initial and overall tenderness of meat, explaining respectively $66 \%$ and $58 \%$ of their variability. Moreover, the content of some HSP27 isoforms in fresh muscle and fragments of this protein in the muscle during ageing explain up to $91 \%$ of the variability in sensorial tenderness (Morzel et al., 2008). However, a study carried out on several beef (charolais and limousin) and hardy (salers) breeds showed that potential markers for tenderness appear to differ from one breed to another. Differences in expression of several proteins (parvalbumin, MLC2, ACBP) connected with calcium metabolism were found between tenderness groups in the two beef breeds, but not in Salers (Bouley et al., 2004b).

Proteomic analysis is also used to track protein changes during meat ageing (Bendixen et al., 2005). In beef, the expression levels most affected during the first 24 hours after slaughter are those of HSP and the energy and protein metabolism enzymes (Jia et al., 2007). Other studies have contributed elements to the understanding of certain meat quality problems, such as PSE meat (Laville et al., 2005) or dark or light cuts of pork (Sayd et al., 2006).

\subsection{Genomics, breeding and nutrition}

In the context of sustainability of breeding systems, controlling the zootechnical performance of animals is of major economic importance. In this field, genomics techniques provide another viewpoint with respect to the molecular links between nutrition and physiology, and more particularly to the interactions between genes and nutrients. An Australian study demonstrated that after 114 days of under-feeding, a large number of genes corresponding either to structural proteins, or to extracellular matrix proteins or to energy metabolism enzymes, are under-expressed, indicating relative atrophy of rapid glycolytic muscle fibres (Lehnert et al., 2006). The muscles of cattle raised at pasture are more oxidative than those of cattle fed maize silage. Transcriptomic analysis of the muscles of these animals (review by Cassar-Malek et al., 2008) revealed differential expression of the gene encoding selenoprotein W (anti-oxidant) which was under-expressed in animals at pasture. Further analysis revealed that the difference in expression is connected with the diet and not the animals' movements. So selenoprotein could be a potential indicator for animals raised at pasture.

\section{4- POTENTIAL APPLICATIONS ISSUED FROM BOVINE GENOMIC RESEARCH AND RESULTS}

\subsection{Improved selection: MAS and genomic selection}

Information on the genes responsible for the genetic variability of traits of interest, or at least on their position, can be used in selection. When a causal mutation is known, increasing the frequency of the favorable allele in breeding stock leads to genetic progress on the considered trait. To some extent, this selection can work without a phenotype recorded on the candidate itself or its progeny, although the 
collection of phenotypic information within the population remains essential. Such a selection procedure based on molecular information is especially interesting when the phenotype is late or costly to obtain, or not measurable on the live animals or incompatible with the breeding animal status, or when it gives little information as for low heritability traits. It is therefore crucial for meat quality, whose precise measurement is complex and requires slaughtering the animals.

Even when the causal mutation is not known, selecting animals using closed markers may lead to the same result. A genetic marker is any genetic polymorphism located near the causal mutation on the genome. Because of their close linkage, they tend to be jointly transmitted from parent to offspring. The availability of a large number of SNP markers covering the entire genome allows, using large and appropriate designs, to very precisely locate the genes of interest and to identify combinations of alleles at the markers associated with the favourable alleles of these genes. Selecting these combinations of markers then leads to the same result as selecting the favourable allele. This is known as marker-assisted selection (MAS). The effectiveness and generality of this approach depends on many factors. The key is the stability of the association of the markers with the gene of interest (or QTL) between the reference population in which this association is highlighted and the population subject to selection. Within a breed, a good efficiency can usually be reached when the markers are sufficiently close to the QTL. But the generalization of the results to different breeds can be difficult, and then the use of reference populations specific to each breed is required. A reference population consists of a large number of individuals, usually with a well defined family structure, and characterized with genetic markers and phenotypes. It could be very expensive to obtain, even if its availability potentially reduces the cost of the later upcoming selection. MUGENE and QUALVIGENE projects are reference populations of this type.

MAS is all the more effective when QTL explain most of the genetic variability. The fact remains that the so-called "polygenic" variability due to a large number of genes each explaining a small effect is not taken into account by the usual MAS programmes. To avoid this problem, we combine all available information, relative to phenotypes, pedigrees and molecular markers (genotypes), in a model that includes individual QTL but also a polygenic component.

A new approach, called "genomic selection" (Meuwissen et al., 2001) is currently emerging, especially in dairy cattle. It uses all the information relative to a huge number of markers throughout the genome to predict statistically the overall genetic value. It makes no reference to any knowledge on individual QTL but seeks to predict the genetic merit from a "black box" model, as did the polygenic model from classical performances and pedigrees. The prediction model is built from a large reference population, in which phenotypes and genotypes are collected, and from which a formula is deduced that is then applied to genotyped candidates. Although it is too early to conclude on its effectiveness, genomic selection is developing very quickly because of its low cost compared to traditional methods of progeny testing and because of the high accuracy it seems to provide, at least at the first generation. The results show that performance recording remains crucial because the quality of prediction rapidly decreases with the number of generations and prediction formula must constantly be updated from recent phenotypes.

\subsection{Towards a better description of phenotypes?}

Genomic techniques have been developed considerably, resulting in increasing quantities of data which now need to be stored and interpreted by association with phenotypic data. 
The first problem to be dealt with is thus the creation and management of appropriate databases. This is more difficult for phenotypic data which, paradoxically, are less numerous but more varied than molecular data. So, researchers today need frames of reference for the measurement of meat and muscle quality, using standardised and reproducible methods. This type of approach was initiated in Australia in the context of the "Meat Standards Australia" database, which is a predictive model for beef quality (Polkinghome et al., 2008). A less ambitious approach was recently started in France (BIF-BEEF project) (Meurice et al., 2008).

The second problem is the need for an ontology system. An international undertaking entitled "Animal Trait Ontology" has been initiated in this connection. One of the goals is to make the comparison of information between species more easy, including laboratory models and agronomical species (Hughes et al., 2008).

The third problem is how to characterize phenotypes in less costly, standardized and rapid fashion in order to make the most of the increasing flow of genomics data. High-throughput phenotyping is currently being developed in the mouse. Nevertheless, assessment of the various meat quality criteria (whether by sensorial analysis, mechanical measurement, fatty acid or other composition factors) will remain complex, laborious and costly. Without any easily acquired phenotypes, the development of routine, high-throughput functional genomics tools could be of considerable help for the characterization of muscle or meat. To do this, and as part of the GENOTEND French project led by INRA, a DNA chip is currently being designed including most of the genes known to have an effect on muscle and meat quality characteristics; the genes in question have emerged from traditional physiological studies or recent work on genomics. This tool has two potential applications:

1) for the physiologist, it will bring a greater understanding of the biochemical variability in muscle characteristics;

2) for the geneticist, the goal is to relate the variability in the genotype to differences in expression of muscle genes. On the long term, we are looking at other complementary high-throughput genomics tools (antibody chips, mass spectrometry (LC/ESI-MS/MS), metabolomic approaches).

At the research level, geneticists can use these expression data like new phenotypes. They have decisive advantages for the identification of the genes and mutations involved. In addition, they point towards the metabolic pathways involved and consequently the candidate genes. They make it possible to discriminate between groups of phenotypes that are similar but differ in their determinism, which is a frequent problem encountered in QTL mapping. Expression data can provide the means for pinpointing the phenotype and concentrating attention on homogenous groups differing only in the QTL being looked for (Schadt et al., 2003). Finally, they can improve the resolution of gene mapping which depends, among other things, on the phenotypic difference between genotypes (Ytournel et al., 2008). The expression of certain genes involved in making a phenotypic difference between genotypes can indeed show far more distinct differences than the macroscopic differences between traditional phenotypes. Once the genes and corresponding mutations have been identified, it is easy to use them in breeding. The use of expression data at various levels (mRNA, proteins, metabolites) could also help to predict which phenotype will be of interest, for example for characterizing the product and its orientation in a segmented market, or its certification. Other authors (Kadarmideen et al., 2006) propose the use of expression phenotypes directly in breeding, instead of or to complement the traditional phenotypic and polymorphism information. This suggestion could provide an attractive solution when the phenotype is difficult to measure, or not very informative. In practice, however, important technical difficulties will need to be overcome, related with the definition of the tissue analyzed (nature, physiologi- 
cal stage), access to it on the living animal, and the logistics and cost of this performance monitoring.

All these prospects for the future also rely heavily on integration (or data association) approaches whatever the level concerned: association of SNP-phenotype or SNP-expression, expression-muscle biochemistry, meat quality prediction, etc. Whatever the case, the concepts of database, reference population, measurement frames of reference and mathematical or statistical tools will lie at the heart of these new lines of research.

\section{5 - CONCLUSION}

The results outlined above highlight how genomics research has made spectacular progress in recent years, particularly in cattle. The completed bovine genome sequencing project together with the release to market - and at reasonable prices of high-throughput microarrays for expression profiling are real revolutions, not just for geneticists but also physiologists. In genetics, the methods used for estimating transmitting ability, which combine pedigree charts with genotyping and phenotyping, warrant ground-up revision, each needing to converge and develop by exploiting the possibilities offered by new "-omics"-based tools (transcriptomics, proteomics and metabolomics). Meanwhile, physiologists have mainly published lists of the muscle genes regulated by farming-related factors or correlated to meat quality, without seeing the bigger picture. However, the major challenge facing biology today is the understanding of phenotypes in terms of interactions between proteins from living systems. This issue is pivotal to meat quality (particularly beef quality), which is the result of complex and highly multifactorial processes. At the forefront are Australian researchers, since they have developed the most comprehensive predictive meat quality grading system ("Meat Standards Australia") available to date. In order to sharpen the system's performance, they intend to integrate new genetic and genomic markers currently in the validation phase. This integrative view is the key to meeting today's challenges.

\section{REFERENCES}

BENDIXEN E., 2005. The use of proteomics in meat science. Meat Sci., 71, 138-149.

BERNARD C., CASSAR-MALEK I., LE CUNFFM., DUBROEUCQ H., RENAND G., HOCQUETTE J.F., 2007. New indicators of beef sensory quality revealed by expression of specific genes. J. Agric. Food Chem., 55, 5229-5237.

BERNARD C., CASSAR-MALEK I., RENAND G., HOCQUETTE J.F., 2009. Changes in muscle gene expression related to meta- bolism according to growth potential in young bulls. Meat Sci., 82, 205-212

BOULEY J., CHAMBON C., PICARD B., 2004a. Mapping of bovine skeletal muscle proteins using two-dimensional gel electrophoresis and mass spectrometry. Proteomics, 4, 1811-1824.

BOULEY J., MEUNIER B., CHAMBON C., DE SMET S., HOCQUETTE J.F., PICARD B., 2005. Proteomic analysis of bovine skele- 
tal muscle hypertrophy. Proteomics, 5, 490-500.

BOULEY J., MEUNIER B., CULIOLI J., PICARD B., 2004b. Proteomic analysis applied to the research of tenderness markers. Renc. Rech. Ruminants, 11, $87-$ 89.

CASSAR-MALEK I., PICARD B., BERNARD C., HOCQUETTE J.F., 2008. Application of gene expression studies in livestock production systems: a European perspective. Aust. J. Exp. Agr., 48, 701-710

CASSAR-MALEK I., PASSELAIGUE F., BERNARD C., LÉGER J., HOCQUETTE J.F., 2007. Target genes of myostatin loss-offunction in muscles of late bovine fetuses. BMC Genomics, 8, 63.

CHAZE T., BOULEY J., CHAMBON C., BARBOIRON C., PICARD B., 2006. Mapping of alkaline proteins in bovine skeletal muscle. Proteomics, 6, 2571-2575.

CHAZE T., MEUNIER B., CHAMBON C., JURIE C., PICARD B., 2008. In vivo proteome dynamics during early bovine myogenesis. Proteomics, 8, 4236-4248.

CHELH I., MEUNIER B., PICARD B., REECY J., CHEVALIER C., HOCQUETTE J.F., CASSAR-MALEK I. 2008. Myostatin knockout alters transcriptomic and proteomic profiles of quadriceps muscle. Proceedings of the $3^{\text {rd }}$ international congress of myology (abstract PW5-061). Myology 2008. May 26-30 ${ }^{\text {th }}$ Marseille (France).

CLOP A., MARCQ F., TAKEDA H., PIROTTIN D., TORDOIR X., BIBE B., BOUIX J., CAIMENT F., ELSEN J.M., EYCHENNE F., LARZUL C., LAVILLE E., MEISH F., MILENKOVIC D., TOBIN J., CHARLIER C., GEORGES M., 2006. A mutation creating a potential illegitimate microRNA target site in the myostatin gene affects muscularity in sheep. Nat. Genet., 38, 813-818.

GAUTIER M., HAYES H., EGGEN A., 2003. A comprehensive radiation hybrid map of bovine Chromosome 26 (BTA26): comparative chromosomal organization between HSA10q and BTA26 and BTA28. Mamm. Genome, 14, 711-721.

GROBET L., PONCELET D., ROYO L.J., BROUWERS B., PIROTTIN D., MICHAUX C., MÉNISSIER F., ZANOTTI M., DUUNNER S., GEORGES M., 1998. Molecular definition of an allelic series of mutations disrupting the myostatin function and cau- sing double-muscling in cattle. Mamm. Genome, 9, 210-213.

GROBET L., MARTIN L.J., PONCELET D., PIROTTIN D., BROUWERS B., RIQUET J., SCHOEBERLEIN A., DUNNER S., MÉNISSIER F., MASSABANDA J., FRIES R., HANSET R., GEORGES M., 1997. A deletion in the bovine myostatin gene causes the double-muscled phenotype in cattle. Nat. Genet., 17, 71-74.

HAMELIN M., SAYD T., CHAMBON C., BOUIX J., BIBÉ B., MILENKOVIC D., LEVEZIEL H., GEORGES M., CLOP A., MARINOVA P., LAVILLE E., 2006. Proteomic analysis of ovine muscle hypertrophy. J Anim. Sci., 84, 3266-3276.

HOCQUETTE J.F., BERNARD C., CASSARMALEK I., LEPETIT J., MICOL D., JURIE C., MEUNIER B., RENAND G., PICARD B., 2007a. Mise en évidence de marqueurs de tendreté de la viande bovine par des approches de génomique fonctionnelle (projet MUGENE). Renc. Rech. Ruminants, 14, 117-120.

HOCQUETTE J.F., LEHNERT S., BARENDSE W., CASSAR-MALEK I., PICARD B., $2007 \mathrm{~b}$. Recent advances in cattle functional genomics and their application to beef quality. Animal, 1, 159-173.

HUGHES L. M., BAO J., HU Z.-L., HONAVAR V., REECY J. M., 2008. Animal trait ontology: The importance and usefulness of a unified trait vocabulary for animal species. J. Anim. Sci., 86, 1485-1491.

JIA X.H., EKMAN M., GROVE H., FAERGESTAD E.M., AASS L., HILDRUM K.I., HOLLUNG K., 2007. Proteome changes in bovine longissimus thoracis muscle during the early postmortem storage period. J. Proteome Res., 6, 2720-2731.

JURIE C., CASSAR-MALEK I., BONNET M., LEROUX C., BAUCHART D., BOULESTEIX P., PETHICK D.W., HOCQUETTE J.F., 2007. Adipocyte fatty acid-binding protein and mitochondrial enzyme activities in muscles as relevant indicators of marbling in cattle. J. Anim. Sci., 85, 26602669.

KADARMIDEEN H.N., VON ROHR P., JANSS L.L., 2006. From genetical genomics to systems genetics: potential applications in quantitative genomics and animal breeding. Mamm. Genome, 6, 548-564.

LAVILLE E., SAYD T., SANTE-LHOUTELLIER V., MORZEL M., LABAS R., FRANCK M., 
CHAMBON C., MONIN G., 2005. Characterisation of PSE zones in semimembranosus pig muscle. Meat Sci., 70, 167-172.

LAVILLE E., SAYD T., TERLOUW C., CHAMBON C., DAMON M., LARZUL C., LEROY P., GLÉNISSON J., CHÉREL P., 2007. Comparison of sarcoplasmic proteomes between two groups of pig muscles selected for shear force of cooked meat. J. Agric. Food Chem., 55, 5834-5841.

LEHNERT S.A., BYRNE K.A., REVERTER A., NATTRASS G.S., GREENWOOD P.L., WANG Y.H., HUDSON NJ, HARPER G.S., 2006. Gene expression profiling of bovine skeletal muscle in response to and during recovery from chronic and severe undernutrition. J. Anim. Sci., 84, 3239-3350.

MEURICE P., BRUN J.P., JURIE C., PICARD B., NUTE G.R., HOCQUETTE J.F., 2008. Meta-analysis of beef sensory quality. Book of Abstracts of the $59^{\text {th }}$ Annual meeting of the European Association for Animal Production, Vilnius 2008, page 162.

MEUWISSEN T.H.E.M., HAYES B.J., GODDARD M.E., 2001. Prediction of total genetic value using genome-wide dense marker maps. Genetics, 157, 1819-1829.

MORZEL M., TERLOUW C., CHAMBON C., MICOL D., PICARD B., 2008. Muscle proteome and meat eating qualities of Longissimus thoracis of "Blonde d'Aquitaine" young bulls: A central role of HSP27 isoforms. Meat Sci., 78, 297-304.

POLKINGHOME R., WATSON R., THOMPSON J.M., PETHICK D.W., 2008. Current usage and future development of the Meat Standards Australia (MSA) grading system. Aust. J. Exp. Agr. 48, 1459-1464.

RENAND G., PICARD B., TOURAILLE C., BERGE P., LEPETIT J., 2001. Relationships between muscle characteristics and meat quality traits of young Charolais bulls. Meat Sci., 59, 49-60.

RENAND G., LARZUL C., BIHAN-DUVAL E., LE ROY P., 2003. Genetic improvement of meat quality in the different livestock species: present situation and prospects. INRA Prod. Anim., 16, 159-173.

RENAND G., LEVEZIEL H., PAYET N., HOCQUETTE J.F., LEPETIT J., DENOYELLE C., DODELIN V., MALAFOSSE A., 2006a. Qualités des carcasses et des viandes de jeunes bovins charolais hétérozygotes pour la mutation q204x de la myostatine. $11^{\text {es }}$ Journées des Sciences du Muscle et
Technologies des Viandes, 4 et 5 octobre 2006, Viandes Prod. Carnés, Hors série, 133-134.

RENAND G., MALAFOSSE A., MENISSIER F., LEVEZIEL H., HOCQUETTE J.F., LEPETIT J., ROUSSET S., DENOYELLE C., DODELIN V., 2006b. Genetic variability of meat quality in the French Charolais, Limousin and Blonde d'Aquitaine beef cattle. In: Proceedings of the $8^{\text {th }}$ World Congress on Genetics Applied to Livestock Production, 13-02.

RENAND G., BONNOT A., LEVEZIEL H., PAYET, N., MALAFOSSE A., HOCQUETTE J.F., LEPETIT J., ROUSSET S., DENOYELLE C., DODELIN V., 2007. Intramuscular lipid content and carcass fatness in specialized beef breeds: genetic variability and two candidate gene marker effects, DGAT1 and Thyroglobulin. Renc. Rech. Ruminants, 14, 113-116.

SAYD T., MORZEL M., CHAMBON C., FRANCK M., FIGWER P., LARZUL C., LE ROY P., MONIN G., CHEREL P., LAVILLE E., 2006. Proteome analysis of the sarcoplasmic fraction of pig Semimembranosus muscle: Implications on meat color development. J. Agric. Food Chem., 54, 27322737.

SCHADT E.E., MONKS S.A., DRAKE T.A., LUSIS A.J., CHE N., COLINAYO V., RUFF T.G., MILLIGAN S.B., LAMB J.R., CAVET G., LINSLEY P.S., MAO M., STOUGHTON R.B., FRIEND S.H., 2003. Genetics of gene expression surveyed in maize, mouse and man. Nature, 422, 297-302.

SCHIBLER L., ROIG A., MAHÉ M.F., SAVE J.C., GAUTIER M., TAOURIT S., BOICHARD D., EGGEN A., CRIBIU., E.P., 2004. A first generation bovine BACbased physical map. Genet. Sel. Evol., 36, 105-122.

SELLNER E.M., KIM J.W., MCCLURE M.C., TAYLOR K.H., SCHNABEL R.D., TAYLOR J.F., 2007. Board-invited review: Applications of genomic information in livestock. J Anim Sci., 85, 3148-3158.

SNELLING W.M., CHIU R., SCHEIN J.E., HOBBS M., ABBEY C.A., ADELSON D.L., AERTS J., BENNETT G.L., BOSDET I.E., BOUSSAHA M., BRAUNING R., CAETANO A.R., COSTA M.M., CRAWFORD A.M., DALRYMPLE B.P., EGGEN A., EVERTS-VAN DER WIND A., FLORIOT S., GAUTIER M., GILL C.A., GREEN R.D., HOLT R., JANN O., JONES S.J., KAPPES 
S.M., KEELE J.W., DE JONG P.J., LARKIN D.M., LEWIN H.A., MCEWAN J.C., MCKAY S., MARRA M.A., MATHEWSON C.A., MATUKUMALLI L.K., MOORE S.S., MURDOCH B., NICHOLAS F.W., OSOEGAWA K., ROY A., SALIH H., SCHIBLER L., SCHNABEL R.D., SILVERI L., SKOW L.C., SMITH T.P., SONSTEGARD T.S., TAYLOR J.F., TELLAM R., VAN TASSELL C.P., WILLIAMS J.L., WOMACK J.E., WYE N.H., YANG G., ZHAO S., 2007. A physical map of the bovine genome. Genome Biol., 8, R165.

SUDRE K., LEROUX C., PIÉTU G., CASSARMALEK I., PETIT E., LISTRAT A., AUFFRAY C., PICARD B., MARTIN P., HOCQUETTE J.F., 2003. Transcriptome analysis of two bovine muscles during ontogenesis. J Biochem., 133, 745-756.

SUDRE K., CASSAR-MALEK I., LISTRAT A., UEDA Y., LEROUX C., JURIE C., AUFFRAY C., RENAND G., MARTIN P., HOCQUETTE J.F., 2005. Biochemical and transcriptomic analyses of two bovine skeletal muscles in Charolais bulls divergently selected for muscle growth. Meat Sci., 70, 267-277.

VAN TASSELL C.P., SMITH T.P., MATUKUMALLI L.K., TAYLOR J.F., SCHNABEL R.D., LAWLEY C.T., HAUDENSCHILD C.D., MOORE S.S., WARREN W.C., SONSTEGARD T.S., 2008. SNP discovery and allele frequency estimation by deep sequencing of reduced representation libraries. Nat. Methods, 5, 247-252.

WANG Y.H., BYRNE K.A., REVERTER A., HARPER G.S., TANIGUCHI M., MCWILLIAM S.M., MANNEN H., OYAMA K., LEHNERT S.A., 2005. Transcriptional profiling of skeletal muscle tissue from two breeds. Mamm. Genome, 16, 201210.

YTOURNEL F., GILBERT H., BOICHARD D., 2008. Comment affiner la localisation d'un QTL? INRA Prod. Anim., 21, 147-158. 